\title{
Revision Arthrodesis of the Sacroiliac Joint
}

\author{
Dr. med. Michael Janka ${ }^{1}$, Dr. med. Adib Hajer ${ }^{2}$, Prof. Dr. Tarun Goyal ${ }^{3}$, Prof. Dr. Stefan \\ Sesselmann ${ }^{4}$, Prof. Dr. med. Alexander Schuh ${ }^{5 *}$ \\ ${ }^{I}$ Musculoskeletal Center, Neumarkt Hospital, 92318 Neumarkt, Germany \\ ${ }^{2}$ Department of Neurosurgery, Marktredwitz Hospital, 95615 Marktredwitz, Germany \\ ${ }^{3}$ Department of Orthopaedics, All India Institute of Medical Sciences, Bathinda, Bathinda, Punjab, India \\ ${ }^{4}$ Institute for Medical Technology, Ostbayerische Technische Hochschule Amberg-Weiden, Hetzenrichter Weg \\ 15, 92637, Weiden, Germany \\ ${ }^{5}$ Department of musculoskeletal research, Marktredwitz Hospital, 95615 Marktredwitz, Germany
}

*Corresponding Author: Prof. Dr. med. Alexander Schuh, Department of Musculoskeletal Research, Marktredwitz Hospital, 95615 Marktredwitz, Germany, Email: A.Schuh@Klinikum-Fichtelgebirge.de

\begin{abstract}
Minimally invasive fusion of the sacroiliac joint (SIJ) is getting more and more popular for the treatment of refractory SIJ dysfunction. Numerous implant devices have been developed with different biomechanical concepts. With increasing number of SIJ arthrodesis problems appear like pseudarthrosis or persistent pain. We report the case of a 39 year young female patient who suffered from persisting pain after distraction arthrodesis of the right SIJ using a Diana screw. After revision, removal of the Diana screw and SIJ arthrodesis using triangular titanium implants the patient is out of complaints till today.
\end{abstract}

Keywords: ISJ, Arthrodesis, Diana, Revision, Triangular Titanium Implants

\section{INTRODUCTION}

Chronic low back pain is a significant public health concern and is one of the most common causes of decreased quality of life. Although lumbar pathology remains a common source, sacroiliac joint (SIJ) dysfunction has become of increasing interest (1-15). Pain from the SIJ has long been recognized as a potential source of chronic low back pain, playing a role in $15 \%$ to $30 \%$ of patients with chronic low back pain (5). While conservative measures may provide some relief, fusion of the SIJ is indicated when nonoperative care has failed to provide persistent improvement. In the past decade, minimally invasive SIJ fusion techniques have become the preferred intervention, having shown superior outcomes to both open SIJ fusion and nonoperative care $(2,5)$. Good to excellent result have been published after SIJ fusion with different implants (1-15). In case of failure of index operation revision arthrodesis is indicated. Causes for revision are typically pain recurrence and radiolucencies around implants (14). Spain et al (14) published the largest series in revision arthrodesis of SIJ after index fusion using cannulated $7.2 \mathrm{~mm}$ diameter stainless steel screws or triangular titanium implants. To our knowledge we report the first case of revision after SIJ fusion with Diana screw using triangular titanium implants.

\section{CASE REport}

In December 2011 distraction arthrodesis of the right SIJ in a 39 years young female patient was performed using Diana screw (SIGNUSMedizintechnik GmbH, Alzenau, Germany)

(Fig.1). One and half year later we saw the patient due to recurrent low back pain with radiation into the right leg. Within the last months several conservative treatment attempts failed. X - ray of the pelvis and the sacrum (Fig.1a and b) showed distraction arthrodesis of right SIJ using Diana screw. CT scan of the pelvis showed no signs of fusion of the right SIJ. Injection test was performed twice under Xray image intensifier control (fig.2). Injection test led to $80 \%$ decrease of pain level. The patient was slightly overweight $(170 \mathrm{~cm}, 85 \mathrm{Kg}$ 
body weight, BMI: 29.4) We recommended and performed revision surgery of the right SIJ, removal of the Diana screw and SIJ arthrodesis using triangular titanium implants (iFuse-3D, (SIBONE, Inc., Santa Clara, CA, USA). The postoperative follow- up was uneventful. The patient was asked to keep partial weight bearing using two crutches for 6 weeks. X- ray of the pelvis and lateral sacrum 2 years after revision surgery showed fusion of the right SIJ joint without radiolucent lines of the three triangular titanium implants. CT scan of the pelvis revealed bony fusion of the right SIJ and correct position of the implants (Fig.3). At latest followup 8 years later the patient is out of any complaints.

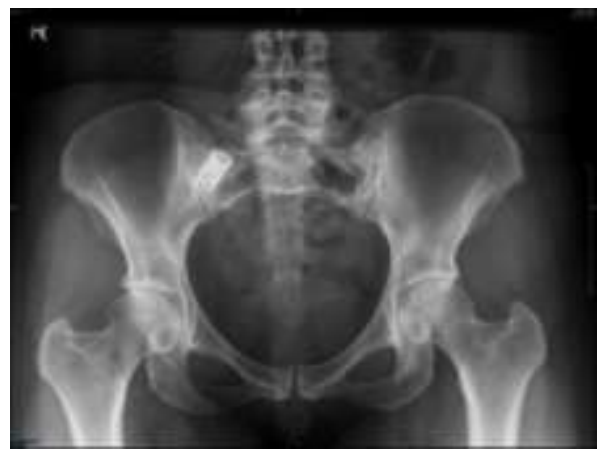

a)

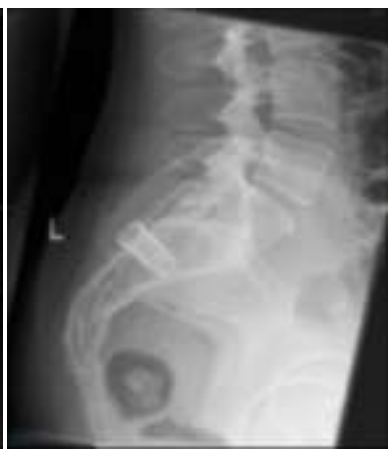

b)

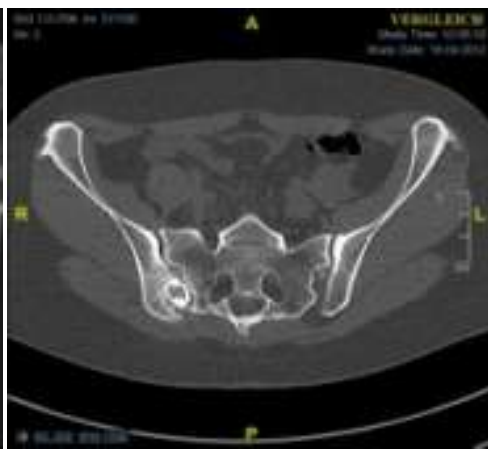

c)

Fig.1. $X$ - ray of the pelvis (a) and lateral view of the sacrum (b) shows distraction arthrodesis of the right SIJ using DIANA screw. CT scan of the pelvis shows no bony fusion of the right SIJ (c).

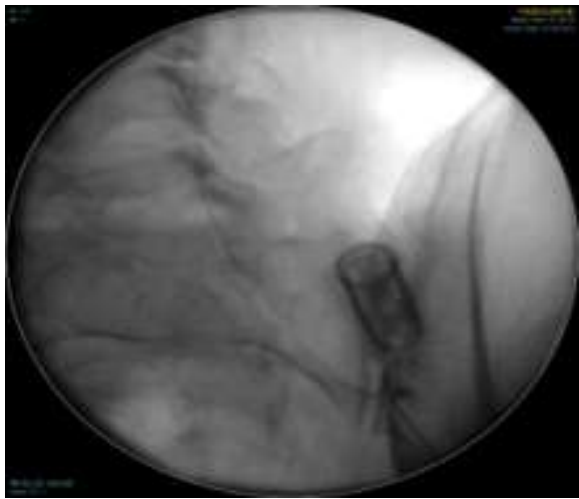

Fig.2. Correct position of the needle during injection test under X-ray image intensifier control

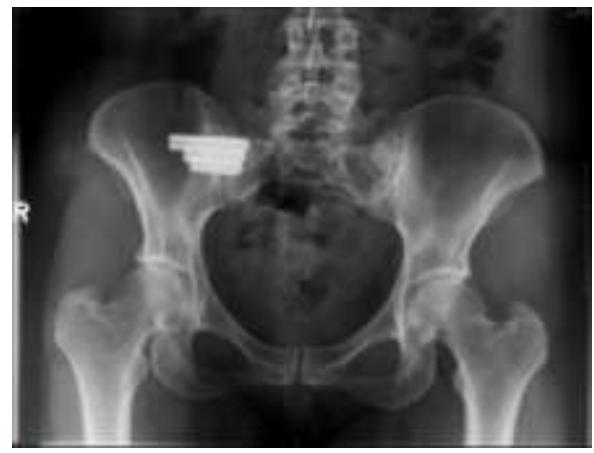

a)

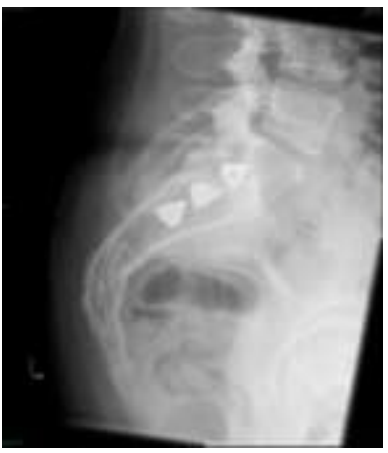

b)

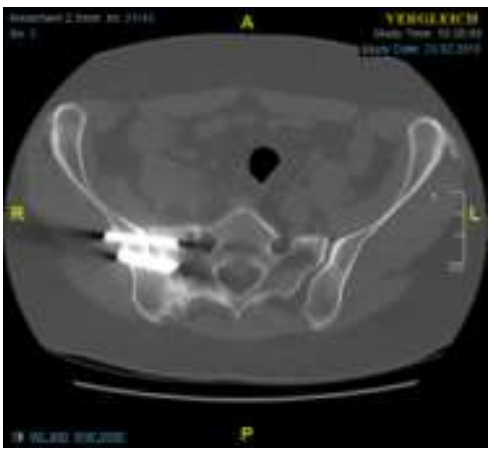

c)

Fig.3. $X$ - ray of the pelvis (a) and lateral view of the sacrum (b) shows arthrodesis of the right SIJ using iFuse$3 D$ implant system. CT scan of the pelvis shows bony fusion of the right SIJ (c)

\section{DISCUSSION}

The prevalence of SI joint dysfunction is difficult to assess but is estimated to occur as high as $62 \%$ in certain populations. Because of a better understanding and significant improvement in surgical techniques, SI joint dysfunction and subsequent fusion have become of increasing interest in spine surgical practice (1). Dengler et al. (5) and Polly et al. (11) postulated that minimally invasive SIJ 
arthrodesis may be a reasonable option for patients with sacroiliac joint pain not responsive to 6 months of conservative management.

Good to excellent results have been published after SIJ fusion with different implants (e.g. Rialto system, SImmetry System. Diana System... ) (1 - 15). Recently Fuchs et al. (8) published 2- year results of distraction arthrodesis of the SIJ using the Diana system in 171 patients. $73 \%$ of all patients felt better or much more better. $49 \%$ of the patients detected reduced pain medication intake. In the follow-up CT scans $31 \%$ of the patients showed SIJ fusion. We follow Endres et al. (7) that careful patient selection is important in SIJ arthrodesis.

Claus et al. (1) recently published a study comparing triangular titanium versus cylindrical threaded implants in SIJ arthrodesis, concluding cylindrical threaded implants showed increased revision rates. Spain et al. (14) compared SIJ arthrodesis using screws or triangular titanium implants and found a significant higher rate of pseudarthrosis in the group using screws. Duhan et al. (6) was able to show that bony fusion takes about up to one year after SIJ fusion using triangular titanium implants. In this series fusion rate of SIJ using triangular titanium implants was $97 \%$.

Another study showed fusion rate of SIJ arthrodesis using triangular titanium implants (iFuse-3D, (SIBONE, Inc., Santa Clara, CA, USA) in $88 \%$ of the patients with excellent clinical results after a 5-year follow-up (15). Spain et al (14) described several failure modes for SIJ fusion using triangular titanium implants including traumatic fracture of the iliac wing secondary to a fall, malposition of the implant and loosening of the implant(s).

To our knowledge we published the first case of revision surgery after SIJ fusion with Diana system using triangular titanium implants (iFuse-3D, (SIBONE, Inc., Santa Clara, CA, USA) with an excellent midterm result.

\section{CONCLUSION}

Symptomatic nonunion after SIJ arthrodesis can be effectively revised in a minimally invasive fashion with positive outcomes using triangular titanium implants. If possible loosened implants should be removed. Future studies are necessary whether preservation of well fixed implants are possible in cases of persisting pain after SIJ arthrodesis.

\section{LITERATURE}

[1] Claus CF, Lytle E, Kaufmann A, et al. Minimally Invasive Sacroiliac Joint Fusion Using Triangular Titanium versus Cylindrical Threaded Implants: A Comparison of PatientReported Outcomes. World Neurosurg. 2020;133:e745-e750.

[2] Cross WW, Delbridge A, Hales D, Fielding LC. Minimally Invasive Sacroiliac Joint Fusion: 2Year Radiographic and Clinical Outcomes with a Principles-Based SIJ Fusion System. Open Orthop J. 2018 Jan 17;12:7-16.

[3] Darr E, Meyer SC, Whang PG, Kovalsky D, Frank C, Lockstadt H, Limoni R, Redmond A, Ploska P, Oh MY, Cher D, Chowdhary A. Long-term prospective outcomes after minimally invasive trans-iliac sacroiliac joint fusion using triangular titanium implants. Med Devices (Auckl). 2018 Apr 9;11:113-121.

[4] Dengler J, Duhon B, Whang P, et al. Predictors of Outcome in Conservative and Minimally Invasive Surgical Management of Pain Originating From the Sacroiliac Joint: A Pooled Analysis. Spine (Phila Pa 1976). 2017;42(21):1664-1673.

[5] Dengler J, Kools D, Pflugmacher R, et al. Randomized Trial of Sacroiliac Joint Arthrodesis Compared with Conservative Management for Chronic Low Back Pain Attributed to the Sacroiliac Joint. J Bone Joint Surg Am. 2019;101(5):400-411. doi:10.2106/JBJS.18.00022

[6] Duhon BS, Bitan F, Lockstadt H, Kovalsky D, Cher D, Hillen T; SIFI Study Group. Triangular Titanium Implants for Minimally Invasive Sacroiliac Joint Fusion: 2-Year Follow-Up from a Prospective Multicenter Trial. Int $\mathrm{J}$ Spine Surg. 2016 Apr 20;10:13. doi: 10.14444/3013.

[7] Endres S, Ludwiget E. Outcome of distraction interference arthrodesis of the sacroiliac joint for sacroiliac arthritis. Indian J Orthop. 2013 Sep-Oct; 47(5): 437 - 442.

[8] Fuchs V, Ruhl B. Distraction arthrodesis of the sacroiliac joint: 2-year results of a descriptive prospective multi-center cohort study in 171 patients. Eur Spine J. 2018;27(1):194-204

[9] MenMuir B, Fielding LC. Revision of Minimally Invasive Sacroiliac Joint Fixation: Technical Considerations and Case Studies Using Decortication and Threaded Implant Fixation. Int J Spine Surg. 2017;11(1):8. Published 2017 Feb 27. doi:10.14444/4008

[10] Patel V, Kovalsky D, Meyer SC, Chowdhary A, Lockstadt H, Techy F, Billys J, Limoni R, Yuan PS, Kranenburg A, Cher D, Tender G. 
Minimally invasive lateral transiliac sacroiliac joint fusion using 3D-printed triangular titanium implants. Med Devices (Auckl). 2019 May 27;12:203-214.

[11] Polly DW, Swofford J , Whang PG, Frank CJ, Glaser JA, Limoni RP, Cher DJ, Wine KD, Sembrano JN. Two-Year Outcomes from a Randomized Controlled Trial of Minimally Invasive Sacroiliac Joint Fusion vs. NonSurgical Management for Sacroiliac Joint Dysfunction. Int J Spine Surg. 2016 Aug 23;10:28. doi: 10.14444/3028.

[12] Rainov NG, Schneiderhan R, Heidecke V. Triangular titanium implants for sacroiliac joint fusion. Eur Spine J. 2019;28(4):727-734.

[13] Sachs D, Kovalsky D, Redmond A, Limoni R, Craig Meyer S, Harvey C, Kondrashov D.
Durable intermediate-to long-term outcomes after minimally invasive transiliac sacroiliac joint fusion using triangular titanium implants. Med Devices (Auckl). 2016 Jul 13;9:213-22. doi: 10.2147/MDER.S109276.

[14] Spain K, Holt T. Surgical Revision after Sacroiliac Joint Fixation or Fusion. Int J Spine Surg. 2017 Jan 19;11(1):5. doi: 10.14444/4005.

[15] Whang PG, Darr E, Meyer SC, Kovalsky D, Frank C, Lockstadt H, Limoni R, Redmond AJ, Ploska P, Oh M, Chowdhary A, Cher D, Hillen T. Long-Term Prospective Clinical And Radiographic Outcomes After Minimally Invasive Lateral Transiliac Sacroiliac Joint Fusion Using Triangular Titanium Implants. Med Devices (Auckl). 2019 Sep 26;12:411422.

Citation: Michael Janka, Adib Hajer, Tarun Goyal, Stefan Sesselmann, Alexander Schuh. "Revision Arthrodesis of the Sacroiliac Joint". 2021; 6(1):14-17. DOI: https://doi.org/10.20431/2456-0588.0601004.

Copyright: (C) 2021 Authors. This is an open-access article distributed under the terms of the Creative Commons Attribution License, which permits unrestricted use, distribution, and reproduction in any medium, provided the original author and source are credited. 